\title{
Soil Resistivity as Related to Underground Corrosion and Cathodic Protection
}

\author{
W. J. Schwerdtfeger
}

(August 4, 1964)

\begin{abstract}
Corrosion data discussed in this paper are based upon measurements made on about 4500 specimens of commonly used plain wrought ferrous materials which had been buried in back-filled trenches at 86 National Bureau of Standards sites for periods up to 17 years. The soils ranged in resistivity from 50 to $54,000 \Omega-\mathrm{cm}$ and in $p \mathrm{H}$ from 2.6 to 10.2 .

Maximum pit depths at 5 years of exposure are taken from pit depth-time curves and the curves are also extrapolated to probable pit depths at 30 years for each of the 86 sites. Furthermore, data on the specimens are adjusted to maximum pit depths that might be expected on a larger area, equivalent to that of the exterior surface of a $20 \mathrm{ft}$ length of 8 in. uncoated wrought ferrous pipe. Maximum penetration rates and pit depths are presented with respect to soil resistivity and $p \mathrm{H}$.

Weight losses which resulted from about 2 years of underground exposure are converted to corrosion current densities and after this period of exposure current densities are calculated from the slopes of weight loss-time curves for each site. On the basis of ratios of protective current to corrosion current obtained from polarization curves on steel specimens underground and in soils in the laboratory, the corrosion current densities can be adjusted to approximate current densities necessary for cathodic protection.
\end{abstract}

\section{Introduction}

Between the years 1922 and 1952 the National Bureau of Standards exposed thousands of metallic specimens at numerous underground sites throughout the United States. Corrosion rates of over 300 varieties of protected and unprotected metals and alloys were evaluated about every 2 years for exposure periods as long as 17 years. The accumulated corrosion data were compiled by Romanoff [1]. ${ }^{1} \quad$ The engineering significance of early NBS data pertaining to some commonly used wrought ferrous materials from the original 47 test sites was discussed in considerable detail by Logan [2]. The present paper is similar but includes data from about 40 additional sites and, based on the total available data, offers suggestions on the current densities probably required for cathodic protection.

In this paper, in addition to extrapolating the average maximum pit depths to 30 years as Logan [2] did, the weight losses of the specimens are converted to corrosion current densities. From these data the approximate current densities required for the cathodic protection of bare underground surfaces can be estimated. Although, based on NBS data, there is no precise relationship between the corrosivity and resistivity of soils, a general relationship is now revealed by the total accumulated data. This is also indicated by the data of Scott [3]. Recently, Schaschl and Marsh [4] discussed the effect of resistivity on the corrosion rates of steel in aqueous environments and showed that for resistivities above $400 \Omega$-cm, the corrosion rate bears an inverse relation to the resistivity of the electrolyte. Thus, a study is undertaken of the influence of soil resistivity, a measurement readily made in the field. The combined relation of $p \mathrm{H}$ and soil resistiv-

\footnotetext{
${ }^{1}$ Figures in brackets indicate the literature references at the end of this paper.
}

ity to corrosion rate was also investigated. The metals to which our data apply are confined to open-hearth iron, hand-puddled and mechanically puddled wrought irons, open-hearth and Bessemer steels, all without added alloying constituents.

\section{Corrosiveness of Soils}

The corrosiveness of a soil might be defined as its destructive or deteriorating effect on a metallic surface, as measured by weight loss and pit depth.

A soil can be potentially corrosive and yet have a negligible effect on plain ferrous materials. This was recently shown by Romanoff [5] as a result of his examination of steel pilings (pulled) exposed from 7 to 40 years in a variety of soils some of which had resistivities as low as $300 \Omega-\mathrm{cm}$. No appreciable amount of corrosion was observed on pile surfaces adjacent to soils into which the piles had been driven below the water table, referred to as "undisturbed" soil. This type of exposure is in contrast to the soil exposure of metals in back-filled trenches, referred to as "disturbed" soil. On driven piling, the corrosion rate decreases rapidly as the initially available oxygen is depleted by the corrosion process and the accessibility of more is limited. In disturbed soils oxygen is more readily replenished and the soil is only very slowly restored to its natural state. This gives rise to differential aeration and then the corrosiveness of the soil depends largely on its physical and chemical properties. Properties of the soils to be considered have already been described [1].

The most severe corrosion usually takes place at low elevations in poorly drained disturbed soils, such as clays and tidal marshes, where, although also poorly aerated, the differential-aeration effects are large because of soil shrinkage. Then too, salts accumulate in these areas and increase the conduc- 
tivity of the soil. The $p \mathrm{H}$ of such soils is usually neutral or in the alkaline range. In contrast, the least corrosive soils are well aerated, well drained and seem to be in areas of high annual precipitation which causes the salts to be washed away and increases the soil resistivity. The $p \mathrm{H}$ is usually between 4 and 7 .

\section{Effect of Area and Duration of Exposure}

The data used in this paper are mostly for accumulated exposure periods of 12 and 14 years. In some soils the accumulated periods are 7 and 17 years. The exposed area of each specimen was about $0.4 \mathrm{ft}^{2}$.

It is of importance to know the effect of larger areas and longer periods of exposure. These variables have been considered by previous investigators $[6,7]$. Years ago, Scott [6] observed that pit depth is a function of the area of metal exposed. Based on National Bureau of Standards data and on data from pipelines, a linear relation was obtained when the logarithm of the average of the deepest pits (several specimens) on a given area was plotted against the logarithm of the area for increasing areas. Thus, for a modest extrapolation of the area, Scott suggested the empirical equation,

$$
\log P=a \log A+\log b, \text { or } P=b A^{a},
$$

where $P$ is the average maximum pit depth on the proposed area $A$, exponent $a$ is the slope of the best linear plot, and $b$ is the average maximum pit depth for a unit area. The useful form of this equation is,

$$
P_{2} / P_{1}=\left(A_{2} / A_{1}\right)^{a} \text { or } P_{2}=P_{1}\left(A_{2} / A_{1}\right)^{a} \text {, }
$$

where $P_{1}$ is the average maximum pit depth on a known area $A_{1}$, and $P_{2}$ is the extrapolated or calculated average maximum pit depth on some assumed area $A_{2}$ for the length of exposure time. Scott suggested as a standard area that of the exterior of a $20 \mathrm{ft}$ length of $8 \mathrm{in}$. diam pipe which is about 45.16 $\mathrm{ft}^{2}$. The values for the exponent, $a$, applicable to specimens in 47 soils have been given by Logan, Ewing, and Denison [7]. Based on their data, the average value of $a=0.15$ has been suggested for use with all soils, as the exponent is apparently not associated with any known soil property [8].

The effect of length of exposure time on rates of corrosion underground is better known than is the effect of area exposed. For example, it is well known that in some soils, after a few years, corrosion seems to cease. The effect of duration of exposure on corrosion rates depends on chemical and physical properties of the soils. Here again, it was observed that a linear relation appears to apply reasonably well between the logarithm of the average of maximum pit depths and the logarithm of the exposure period. This is expressed by the equation,

$$
\log P=n \log T+\log k \text {, or } P=k T^{n},
$$

where $P$ is the average maximum pit depth at some time $T, n$ is the slope of the line of best fit, and $k$ is the average maximum pit depth for a unit of time. Again, the useful form of the relation becomes,

$$
P_{2} / P_{1}=\left(T_{2} / T_{1}\right)^{n} \text { or } P_{2}=P_{1}\left(T_{2} / T_{1}\right)^{n} \text {, }
$$

where $P_{1}$ is the average maximum pit depth for the shorter period of exposure $T_{1}$, and $P_{2}$ is the average maximum pit depth at some longer time $T_{2}$. Logan, Ewing, and Denison [7] divided 47 NBS soil sites into 4 groups based on aeration and on drainage, ranging from well-aerated sands and sandy loams to tidal marshes. The exponent, $n$, was derived for each soil group and ranged from $n=0.19$ for soils having good aeration to $n=0.68$ for soils with very poor aeration, such as clays and tidal marshes. More recently, Scott [9] has proposed that the average rate of corrosion underground is inversely proportional to the square root of the duration of exposure time, that is, in eq (3), $n=0.5$.

\section{Discussion of the Data}

\subsection{Maximum Pit Depths}

The maximum pit depth data for 86 soil sites are given in table 1 and graphically presented with respect to soil resistivity and $p \mathrm{H}$ in figures 1 through 5. Figure 1 shows maximum pit depths on the specimens at 5 years taken from pit depth-time curves (not shown). On the average, pits are somewhat deeper in the soils with resistivities below $500 \Omega-\mathrm{cm}$ than in soils with higher resistivities but above 500 $\Omega$-cm there appears to be no regular variation between pit depth and soil resistivity. However, the relationship looks different when the rate of maximum penetration after 5 years is plotted versus resistivity, as shown in figure 2 . The data were calculated from the straight lines through points on the pit depth-time curves using rectangular coordinates. There now appears to be a definite trend to lesser pitting rates as resistivity increases. The effect of $p \mathrm{H}$ of the soil on maximum penetration rates is shown in figure 3 . Note that the majority of very corrosive soils $(<500 \Omega-\mathrm{cm})$ are in the alkaline range $(>p \mathrm{H} 7)$.

The effect on maximum penetration of increasing the area exposed from that of a specimen (about 0.4 $\mathrm{ft}^{2}$ ) to a larger area (equivalent to that of a $20 \mathrm{ft}$ length of 8 in. diam pipe) exposed to identical soil conditions, by calculations previously described, is shown in figure 4. Data pertaining to the effect of increased area are tabulated in table 1.

The estimated effect of increasing exposure time from 5 to 30 years is also shown in table 1 , as based on linear extrapolation of data plotted on both rectangular and logarithmic coordinates. As would be expected, the pit depths extrapolated from log pit depth-log time curves are for the majority of soils somewhat smaller than the values from rectangular coordinates. Previous investigators, [7] whose work resulted in eq (3), favored the logarithmic relationship and their conclusions seem to be reasonable. 


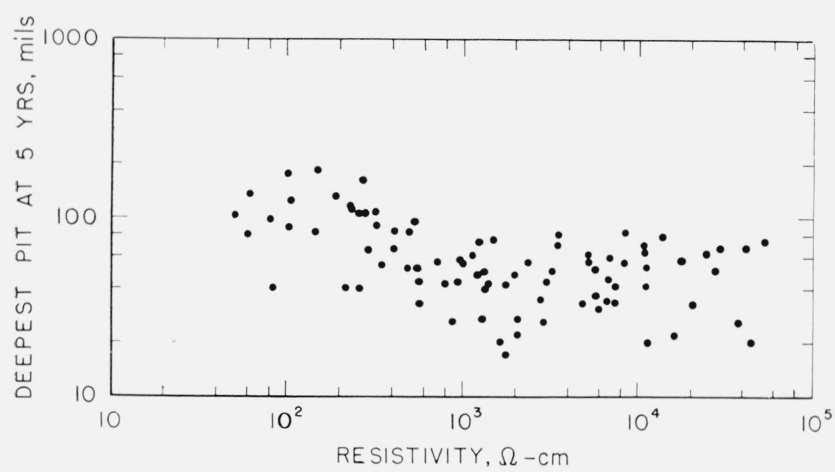

Figure 1. Average of maximum pit depths on from 6 to 14 ferrous specimens buried in each of 86 underground soil sites.

Pit depths are taken from the pit depth versus time curves at 5 years.

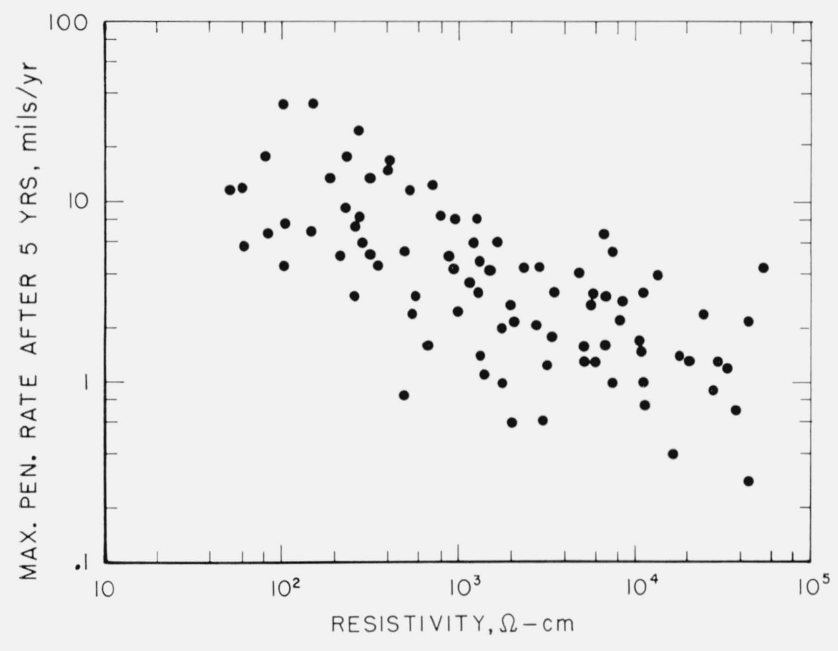

Figure 2. Rates of penetration of the specimens (fig. 1), based on the maximum pit depth versus time curves, from 5 years to from 12 to 17 years (for the majority of the soils).

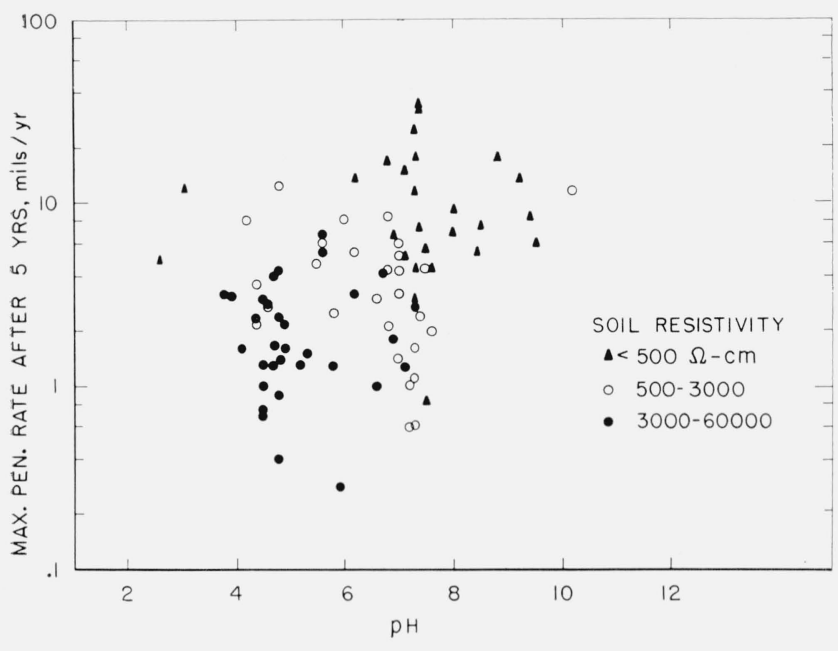

Figure 3. Maximum rates of penetration (fig. 2) on specimens as related to $\mathrm{pH}$ for 3 ranges of soil resistivity.

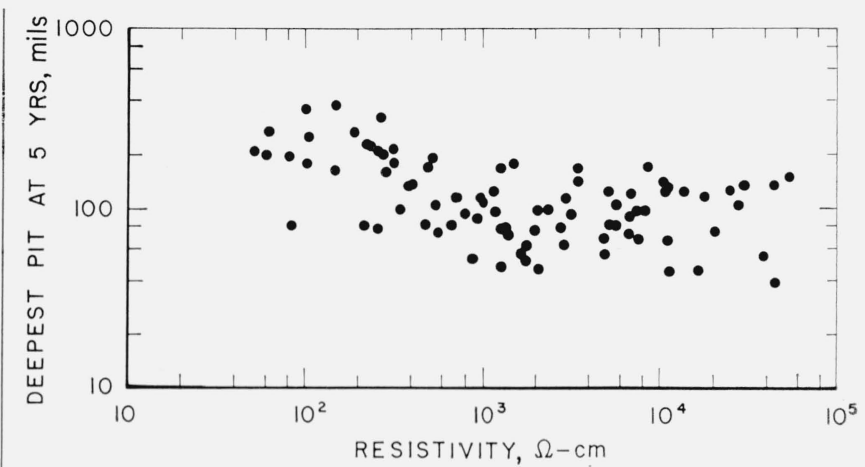

Figure 4. Maximum pit depths at 5 years of underground exposure calculated for larger areas (equivalent to $20 \mathrm{ft}$ of $8 \mathrm{in}$. diam bare pipe) from data on small pipe specimens (fig. 1).

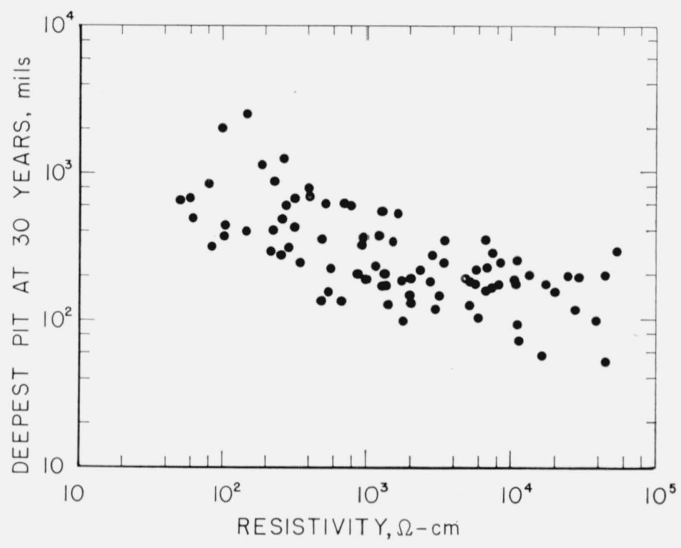

FIgURE 5. Same as figure 4, except that the exposure time is extrapolated to 30 years.

Data adjusted for the larger area shown in the last column table 1, are plotted against soil resistivity figure 5. Perforation of a pipe wall, ranging in thickness from 0.172 in. to 0.322 in. for 8 in. diam steel pipe, is predicted in almost all soils having resistivities less than $1000 \Omega-\mathrm{cm}$. In some of these soils, many perforations would probably occur. For soils with resistivities over $2000 \Omega$-cm, and assuming the absence of stray currents or contact with more noble metals, the extrapolated data indicate that perforation of 8 in. diam (0.322 in. wall-thickness) steel pipe in 30 years is rather unlikely. However, the data definitely show the need for protective measures, such as coatings, cathodic protection or both, on wrought materials exposed to soils with resistivities less than $2000 \Omega-\mathrm{cm}$ and also even in some soils of higher resistivity, as indicated by predicted pit depths in a few of the soils shown above $25,000 \Omega$-cm, all depending on the hazard involved should a perforation occur.

Recent work by Scott [3, 9] has a direct bearing on the relation between soil resistivity and maximum penetration. Based on random measurements of soil resistivity in the field he found that a plot on log-probability coordinates of soil resistivity measurements for a given area versus estimated cumulative probability assumes a linear relationship in many 
TABLE 1. Maximum pit-depth a

\begin{tabular}{|c|c|c|c|c|c|c|c|c|c|}
\hline & & & & Time & $-5 \mathrm{yrs}$ & & & ime -30 yrs & \\
\hline $\begin{array}{l}\text { Soil site } \\
\text { No. b }\end{array}$ & $\rho^{\mathrm{c}}$ & $p \mathrm{H}$ & $\begin{array}{l}\text { Internal } \\
\text { drainage }{ }^{d}\end{array}$ & $\begin{array}{l}\text { Specimen } \\
\text { area } A_{1} \text { e }\end{array}$ & $\begin{array}{l}\text { Assumed } \\
\text { area } A_{2} \text { f }\end{array}$ & $\begin{array}{l}\text { pitting rate } \\
\text { after } 5 \text { yrs } \mathrm{g}\end{array}$ & $\begin{array}{l}\text { Specimen } \\
\text { rectangular h } \\
\text { co-ord }\end{array}$ & $\begin{array}{l}\text { Specimen } \\
\text { log-co-ord } \mathrm{i}\end{array}$ & $\begin{array}{l}\text { Assumed } \\
\text { area } A_{2} \text { j }\end{array}$ \\
\hline & $\Omega-c m$ & & & Mils & Mils & Mils/yr & Mils & Mils & Mits \\
\hline $\begin{array}{l}1 \\
2\end{array}$ & $\begin{array}{r}1215 \\
684\end{array}$ & $\begin{array}{l}7.0 \\
7.3\end{array}$ & $\mathrm{P}$ & 48 & 96 & 6.0 & 198 & 190 & 378 \\
\hline $\begin{array}{l}2 \\
3\end{array}$ & $\begin{array}{r}684 \\
30000\end{array}$ & $\begin{array}{l}7.3 \\
5\end{array}$ & $\mathrm{P}$ & 44 & 82 & 1.6 & 84 & 72 & 134 \\
\hline $\begin{array}{l}3 \\
4\end{array}$ & & 5. 2 & G & 68 & 134 & 1.3 & 101 & 97 & 192 \\
\hline 5 & $\begin{array}{l}0600 \\
1345\end{array}$ & 5.6 & F & 34 & 72 & 6.7 & 202 & 165 & 351 \\
\hline 6 & $\begin{array}{r}1070 \\
45100\end{array}$ & $\begin{array}{l}7.0 \\
5.9\end{array}$ & $\mathrm{P}$ & 40 & 79 & 1.4 & 75 & 86 & 170 \\
\hline 7 & 2120 & $\begin{array}{l}5.9 \\
4.4\end{array}$ & $\stackrel{\mathrm{G}}{\mathrm{F}}$ & 20 & 39 & 0.28 & 27 & 26 & 52 \\
\hline 8 & 350 & 7.6 & $\stackrel{F}{P}$ & 27 & 47 & 2.2 & 82 & 76 & 131 \\
\hline 9 & 2820 & 6.8 & $\stackrel{\mathrm{P}}{\mathrm{P}}$ & 54 & 100 & 4. 4 & 164 & 130 & 244 \\
\hline 10 & 7460 & 6.6 & $\stackrel{\mathrm{P}}{\mathrm{F}}$ & $\begin{array}{l}35 \\
41\end{array}$ & $\begin{array}{l}79 \\
98\end{array}$ & 2.1 & 88 & 82 & 185 \\
\hline 11 & 11000 & 5. 3 & G & $\begin{array}{l}41 \\
64\end{array}$ & $\begin{array}{r}98 \\
124\end{array}$ & $\begin{array}{l}1.0 \\
1.5\end{array}$ & $\begin{array}{r}66 \\
102\end{array}$ & $\begin{array}{l}70 \\
90\end{array}$ & $\begin{array}{l}167 \\
174\end{array}$ \\
\hline 12 & 3190 & 7.1 & G & 50 & 97 & 1.3 & 83 & 75 & $\begin{array}{l}174 \\
145\end{array}$ \\
\hline 13 & 290 & 9.5 & F & 65 & 161 & 6.0 & 215 & 125 & 311 \\
\hline 14 & 3520 & 6.2 & $\mathrm{~F}$ & 80 & 169 & 3. 2 & 160 & 165 & 348 \\
\hline 15 & 489 & 7.5 & P & 52 & 83 & 0.84 & 73 & 84 & 134 \\
\hline 16 & 8290 & 4.4 & $\mathrm{~F}$ & 56 & 98 & 2.3 & 114 & 100 & 175 \\
\hline 17 & 5980 & 4.5 & $\mathrm{~F}$ & 31 & 56 & 1.3 & 64 & 57 & 103 \\
\hline 18 & 1410 & 7.3 & G & 43 & 72 & 1.1 & 71 & 76 & 128 \\
\hline 19 & 1970 & 4. 6 & G & 48 & 77 & 2.7 & 116 & 92 & 148 \\
\hline 20 & 2870 & 7.5 & $\mathrm{P}$ & 26 & 63 & 4.4 & 136 & 115 & 278 \\
\hline 21 & 2370 & 6.2 & $\mathrm{~F}$ & 56 & $\begin{array}{r}5 \\
103\end{array}$ & $\begin{array}{l}4.4 \\
4.4\end{array}$ & 110 & 120 & 220 \\
\hline 22 & 5150 & 4.9 & G & 56 & 83 & $\begin{array}{l}4.4 \\
1.6\end{array}$ & 96 & 85 & 125 \\
\hline 23 & 278 & 9.4 & $\mathrm{~F}$ & 105 & 200 & $\begin{array}{l}8.0 \\
8.3\end{array}$ & $\begin{array}{r}512 \\
312\end{array}$ & 310 & 597 \\
\hline 24 & 11400 & 4.5 & G & 20 & 45 & 0.75 & 39 & 32 & 72 \\
\hline 25 & 1780 & 7.2 & $\mathrm{~F}$ & 42 & 63 & 1.0 & 67 & 65 & 98 \\
\hline 26 & 2980 & 7.3 & G & 60 & 114 & 0.61 & 77 & 67 & 118 \\
\hline 27 & 570 & 6.6 & VP & 33 & 74 & 3. 0 & 108 & 100 & 223 \\
\hline $\begin{array}{l}28 \\
20\end{array}$ & 408 & 6.8 & VP & 83 & 137 & 17. 0 & 508 & 420 & 693 \\
\hline${ }_{30}^{29}$ & 1270 & 4. 2 & VP & 73 & 169 & 8.1 & 276 & 235 & 545 \\
\hline${ }_{31}^{30}$ & 1300 & 7.0 & $\mathrm{P}$ & 27 & 48 & 3.2 & 107 & 95 & 170 \\
\hline 31 & 20500 & 4.7 & G & 33 & 75 & 1.3 & 66 & 69 & 156 \\
\hline 32 & 5700 & 7.3 & G & 37 & 81 & 2.7 & 105 & 81 & 177 \\
\hline 33 & 800 & 6.8 & VP & 43 & 95 & 8.4 & 253 & 270 & 598 \\
\hline 34 & 4900 & 6.7 & $\mathrm{~F}$ & 33 & 69 & 4.1 & 136 & 92 & 193 \\
\hline 35 & 2060 & 7.3 & G & 22 & 99 & 0.60 & 37 & 43 & 193 \\
\hline 36 & 11200 & 4.5 & G & 42 & 67 & 1.0 & 67 & 58 & 92 \\
\hline 37 & 11200 & 3.8 & $\mathrm{P}$ & 53 & 131 & 3.2 & 133 & 103 & 254 \\
\hline 38 & 38600 & 4.5 & G & 26 & 54 & 0.7 & 44 & 48 & 99 \\
\hline 39 & 7440 & 5.6 & F & 34 & $\begin{array}{l}69 \\
\end{array}$ & 5.4 & 169 & 140 & 284 \\
\hline 40 & 970 & 6.0 & $\mathrm{P}$ & 58 & 115 & 8.1 & 261 & 185 & 365 \\
\hline 41 & 1320 & 5.5 & $\mathrm{~F}$ & 50 & 78 & 4.7 & 168 & 130 & 203 \\
\hline 42 & 13700 & 4.7 & $\mathrm{~F}$ & 79 & 125 & 4.0 & 179 & 135 & 214 \\
\hline 43 & 60 & 3.1 & VP & 80 & 201 & $\begin{array}{r}12.0 \\
\text { r. }\end{array}$ & 285 & 270 & 678 \\
\hline 44 & 1000 & 5.8 & G & 55 & 111 & 2.5 & 118 & 95 & 191 \\
\hline 45 & 263 & 7.4 & $\mathrm{P}$ & 40 & 78 & 7.3 & 223 & 240 & 469 \\
\hline 46 & 1500 & 70 & $\mathrm{G}$ & 75 & 181 & 4.2 & 180 & 140 & 337 \\
\hline 47 & 1770 & 7.6 & $\mathrm{P}$ & 17 & 52 & 2.0 & 67 & 60 & 183 \\
\hline 51 & 190 & 6.2 & VP & 131 & 266 & 13.6 & 471 & 550 & 1117 \\
\hline 53 & 17790 & 4.8 & G & 58 & 118 & 1. 4 & 93 & 87 & 177 \\
\hline 55 & 5210 & 5.8 & G & 62 & 126 & 1.3 & 95 & 90 & 183 \\
\hline 56 & 406 & 7.1 & VP & 66 & 134 & 15. 0 & 441 & 390 & 792 \\
\hline 58 & 712 & 4.8 & VP & 57 & 116 & 12.6 & 372 & 305 & 619 \\
\hline 59 & $\begin{array}{r}1660 \\
210\end{array}$ & 5.6 & VP & 28 & 57 & 6.0 & 178 & 260 & $\begin{array}{r}528 \\
\end{array}$ \\
\hline 60 & 218 & 2. 6 & P & 40 & 81 & 5. 0 & 165 & 145 & 294 \\
\hline 61 & 943 & 6.8 & $P$ & 44 & 89 & 4.3 & 152 & 160 & 325 \\
\hline 62 & 6920 & 4.5 & $\mathrm{~F}$ & 60 & 122 & 3. 0 & 135 & 110 & 223 \\
\hline 63 & 84 & 6.9 & VP & 40 & 81 & 6.7 & 208 & 155 & 314 \\
\hline 64 & 62 & 7.5 & $\mathrm{~F}$ & 134 & 272 & 5.7 & 277 & 240 & 487 \\
\hline 65 & 148 & 8.0 & G & 82 & 166 & 6.9 & 255 & 195 & 396 \\
\hline 66 & 232 & 8.0 & F & 112 & 228 & 6.0 & 262 & 200 & 406 \\
\hline 52 & 234 & 8.8 & VP & 110 & 223 & 18.0 & 560 & 430 & 873 \\
\hline 54 & 886 & 7.0 & $\mathrm{P}$ & 26 & 53 & 5.1 & 154 & 100 & 203 \\
\hline 101 & 261 & 7.3 & $\mathrm{~F}$ & 104 & 211 & 3.0 & 179 & 135 & 274 \\
\hline 102 & 103 & 7.3 & $\mathrm{~F}$ & 88 & $\begin{array}{l}179 \\
\text {. }\end{array}$ & 4.4 & 198 & 185 & 376 \\
\hline 103 & 81 & 7.3 & F & 97 & 197 & $\begin{array}{r}17.9 \\
\end{array}$ & 544 & 420 & 853 \\
\hline 104 & 8500 & 4.6 & G & 84 & 171 & 2.8 & 154 & 120 & 244 \\
\hline 105 & 28000 & 4.8 & G & $\begin{array}{l}0+ \\
51\end{array}$ & $\begin{array}{l}1 \\
104\end{array}$ & $\begin{array}{l}0.9 \\
0.9\end{array}$ & 74 & 58 & 117 \\
\hline 106 & 25000 & 4.8 & G & $\begin{array}{l}01 \\
63\end{array}$ & 128 & $\begin{array}{l}0.0 \\
2.4\end{array}$ & 123 & 98 & 199 \\
\hline 107 & 54000 & 4.8 & G & 74 & 150 & 4.3 & 182 & 145 & 294 \\
\hline 108 & 44400 & 4.8 & G & 68 & 138 & 2.2 & 123 & 100 & 203 \\
\hline 109 & 497 & 8.4 & $\mathrm{P}$ & 83 & $\begin{array}{l}1690 \\
169\end{array}$ & 5.4 & 218 & 175 & 355 \\
\hline 110 & 531 & 10.2 & $\mathrm{P}$ & 95 & 193 & 11. 7 & 388 & 300 & 609 \\
\hline 111 & 51 & 7.3 & $\mathrm{P}$ & 102 & 207 & 11.8 & 397 & 320 & 650 \\
\hline 112 & 149 & 7.4 & $\mathrm{P}$ & 185 & 375 & 35.0 & 1060 & 1250 & 2530 \\
\hline 113 & 102 & 7.4 & $\mathrm{~F}$ & 177 & 360 & 35.0 & 1052 & 1000 & 2030 \\
\hline 114 & 320 & 7.1 & VP & 89 & 181 & 5.1 & 217 & 210 & 426 \\
\hline 115 & 3450 & 6.9 & G & 70 & 142 & 1.8 & 115 & 120 & 244 \\
\hline 116 & 320 & 9.2 & $\mathrm{~F}$ & 107 & 217 & 13.7 & 450 & 330 & 670 \\
\hline 117 & 106 & 8.5 & $\mathrm{P}$ & 123 & 250 & 7.6 & 313 & 215 & 437 \\
\hline 118 & 273 & 7.3 & $\mathrm{~F}$ & 160 & 325 & 25.4 & 795 & 610 & 1240 \\
\hline 119 & 10800 & 4.7 & G & 70 & 142 & 1.7 & 113 & 93 & 189 \\
\hline 121 & 16400 & 4.8 & G & 22 & 45 & 0.4 & 32 & 28 & 57 \\
\hline 122 & 552 & 7.4 & $\mathrm{~F}$ & 52 & 106 & 2.4 & 112 & 77 & 156 \\
\hline 123 & 6840 & 4.1 & $\mathrm{P}$ & 45 & 91 & 1.6 & 85 & 78 & 158 \\
\hline 124 & 1160 & 4.4 & P & 62 & 126 & 3.6 & 152 & 115 & 233 \\
\hline 125 & 5770 & 3.9 & $\mathrm{P}$ & 52 & 106 & 3.1 & 130 & 110 & 223 \\
\hline
\end{tabular}

a Average of the deepest pits on 6 to 14 specimens (area, approximately $0.4 \mathrm{ft}^{2}$ ) for each soil.

(1) table 6 .

Soil resistivity, saturated soil at $60^{\circ} \mathrm{F}$

VP, very poor

e Romanoff [1], from pit depth-time curves using data in tables 13, 14, 15. There were from 6 to 14 specimens involved in each removal from a given soil and from 3 to 6 removals, the 3 removals being for the 100 series of soils. f $A_{0}=45.16 \mathrm{ft}^{2}$, equivalent to a $20 \mathrm{ft}$ length of 8 in pipe See eq (2). For soils 1 through 47, used exponents $a$, from Logan, Ewing, and Denison [7]. For all other soils, used exponent $a=0.15$, from schwerdtfeger (8).

$\mathrm{g}$ Based on best straight line after 5 years on pit depth-time curves on linear coordinates.

h Extrapolated pit depth-time curves.

i Extrapolated pit depth-time curves.

i From log-coordinates (i) and use of eq (2). 
areas and is therefore indicative of a uniform environment. Later, Scott offered a theoretical basis for his empirical relationship [10]. Soil resistivity measurements made by him along pipeline rights-ofway together with leak records on the pipelines show that leaks occur in the places of low resistivity and almost invariably at resistivities below the value shown by 50 percent probability on the $\log$ resistivity-probability curve.

\subsection{Relation Between Weight Losses and Currents Required for Cathodic Protection}

The weight losses on the specimens for which maximum penetration has been given were converted to corrosion current densities by applying Faraday's law and the usual assumptions that the iron was oxidized to the divalent state and the corrosion efficiency was 100 percent. The data tabulated in table 2 are based on weight losses measured at 2-year removal time and on removals after 5 years. The corrosion rates, expressed as current densities, plotted versus soil resistivity and $p \mathrm{H}$ are shown in figures 6 , 7 , and 8 . The current densities calculated from the weight losses of specimens based on the first removals (approximately 2 years for most specimens) are shown plotted versus soil resistivity in figure 6 . What was previously said about the significance of $500 \Omega-\mathrm{cm}$ as a dividing line for differences in maximum penetration during early exposure also seems to apply to the current densities associated with corrosion. The effect of soil resistivity in substantially reducing corrosion current densities for exposure beyond 5 years is illustrated by figure 7 . These data are the result of straight lines on rectangular coordinates drawn through the weight losses after 5 years on the weight loss-time curves (not shown). The same data as related to soil $p H$ are shown in figure 8 .

These corrosion currents are primarily of interest in connection with current densities necessary for cathodic protection. The relationship between values of corrosion current and current required for cathodic protection depends on the type of control of the corrosion reaction. Theoretically, if the reaction is under strict cathodic control (no anodic polarization), the protective current is equal in magnitude to the corrosion current. This ideal situation is not usually realized with ferrous metals used underground, the protective current requirement being somewhat greater. For further information on this relationship and some data, the reader is referred to papers by the author $[11,12]$ and other investigators $[13,14,15]$. Data obtained on steel pipe specimens exposed underground showed that the ratio, $I_{p} / i_{0}$, of protective current, $I_{p}$, to corrosion current, $i_{0}$, varied between 1 and 2, depending on the length of time the specimens were exposed and on the chemical and physical properties of the soil. For example, in the case of a specimen buried in a soil of $7500 \Omega-\mathrm{cm}$ resistivity, the ratio was about 1.3 during the first week of burial and around 2.0 at 6 months and thereafter for 16 months exposure when the specimen was removed [16]. For a similar specimen (area,
TABLE 2. Corrosion currents associated with weight losses o* specimens ${ }^{a}$

\begin{tabular}{|c|c|c|c|c|c|c|c|}
\hline \multirow{2}{*}{$\begin{array}{l}\text { Soil } \\
\text { site } \\
\text { No. }{ }^{b}\end{array}$} & \multirow[b]{2}{*}{$\rho^{\mathrm{c}}$} & \multicolumn{2}{|c|}{ Corrosion rate } & \multirow{2}{*}{$\begin{array}{l}\text { Soil } \\
\text { site } \\
\text { No.b }\end{array}$} & \multirow[b]{2}{*}{$\rho^{\mathrm{c}}$} & \multicolumn{2}{|c|}{ Corrosion rate } \\
\hline & & $0-2 \mathrm{yr}^{\mathrm{d}}$ & $\begin{array}{c}\text { After } 5 \\
\text { yr e }\end{array}$ & & & $0-2 \mathrm{yr}^{\mathrm{d}}$ & $\begin{array}{c}\text { After } 5 \\
\text { yr e }\end{array}$ \\
\hline $\begin{array}{l}1 \\
2 \\
3 \\
4 \\
5\end{array}$ & $\begin{array}{r}\Omega-c m \\
1215 \\
684 \\
30000 \\
6670 \\
1345\end{array}$ & $\begin{array}{c}m A / f t^{2} \\
3.7 \\
3.1 \\
2.8 \\
3.1 \\
1.8\end{array}$ & $\begin{array}{l}m A / f t^{2} \\
2.0 \\
1.1 \\
0.41 \\
1.3 \\
1.1\end{array}$ & $\begin{array}{l}51 \\
53 \\
55 \\
56 \\
58\end{array}$ & $\begin{array}{r}\Omega-c m \\
190 \\
17790 \\
5210 \\
406 \\
712\end{array}$ & $\begin{array}{c}m A / f t^{2} \\
14.2 \\
5.0 \\
4.4 \\
6.5 \\
5.2\end{array}$ & $\begin{array}{c}m A / f t t^{2} \\
3.6 \\
0.50 \\
0.41 \\
6.5 \\
3.4\end{array}$ \\
\hline $\begin{array}{r}6 \\
7 \\
8 \\
9 \\
10\end{array}$ & $\begin{array}{r}45100 \\
2120 \\
350 \\
2820 \\
7460\end{array}$ & $\begin{array}{l}0.28 \\
1.1 \\
1.8 \\
2.3 \\
2.9\end{array}$ & $\begin{array}{l}0.26 \\
0.59 \\
1.8 \\
1.0 \\
1.1\end{array}$ & $\begin{array}{l}59 \\
60 \\
61 \\
62 \\
63\end{array}$ & $\begin{array}{r}1660 \\
218 \\
943 \\
6920 \\
84\end{array}$ & $\begin{array}{l}2.5 \\
8.4 \\
3.4 \\
5.3 \\
4.7\end{array}$ & $\begin{array}{l}1.6 \\
5.6 \\
1.6 \\
1.1 \\
2.5\end{array}$ \\
\hline $\begin{array}{l}11 \\
12 \\
13 \\
14 \\
15\end{array}$ & $\begin{array}{r}11000 \\
3190 \\
290 \\
3520 \\
489\end{array}$ & $\begin{array}{l}0.90 \\
1.3 \\
5.6 \\
1.7 \\
3.6\end{array}$ & $\begin{array}{l}0.34 \\
0.81 \\
3.6 \\
1.1 \\
1.8\end{array}$ & $\begin{array}{l}64 \\
65 \\
66 \\
52 \\
54\end{array}$ & $\begin{array}{r}62 \\
148 \\
232 \\
234 \\
886\end{array}$ & $\begin{array}{r}20.3 \\
9.4 \\
12.5 \\
6.2 \\
1.5\end{array}$ & $\begin{array}{r}12.7 \\
1.4 \\
2.8 \\
6.2 \\
1.1\end{array}$ \\
\hline $\begin{array}{l}16 \\
17 \\
18 \\
19 \\
20\end{array}$ & $\begin{array}{l}8290 \\
5890 \\
1410 \\
1970 \\
2870\end{array}$ & $\begin{array}{l}\text { 3. } 6 \\
\text { 3. } 1 \\
\text { 1. } 2 \\
\text { 2. } 0 \\
2.9\end{array}$ & $\begin{array}{l}1.7 \\
1.1 \\
0.56 \\
0.53 \\
1.5\end{array}$ & $\begin{array}{l}101 \\
102 \\
103 \\
104 \\
105\end{array}$ & $\begin{array}{r}261 \\
103 \\
81 \\
8500 \\
28000\end{array}$ & $\begin{array}{l}7.0 \\
7.2 \\
6.9 \\
4.6 \\
5.3\end{array}$ & $\begin{array}{l}2.2 \\
5.6 \\
6.6 \\
1.5 \\
0.31\end{array}$ \\
\hline $\begin{array}{l}21 \\
22 \\
23 \\
24 \\
25\end{array}$ & $\begin{array}{r}2370 \\
5150 \\
278 \\
11400 \\
1780\end{array}$ & $\begin{array}{c}4.1 \\
2.9 \\
11.2 \\
0.62 \\
1.3\end{array}$ & $\begin{array}{l}1.5 \\
0.72 \\
4.7 \\
0.22 \\
0.65\end{array}$ & $\begin{array}{l}106 \\
107 \\
108 \\
109 \\
110\end{array}$ & $\begin{array}{r}25000 \\
54000 \\
44400 \\
497 \\
531\end{array}$ & $\begin{array}{l}3.9 \\
3.6 \\
5.2 \\
8.7 \\
6.9\end{array}$ & $\begin{array}{l}1.9 \\
1.0 \\
0.59 \\
2.6 \\
6.2\end{array}$ \\
\hline $\begin{array}{l}26 \\
27 \\
28 \\
29 \\
30\end{array}$ & $\begin{array}{r}2980 \\
570 \\
408 \\
1270 \\
1300\end{array}$ & $\begin{array}{l}2.2 \\
\text { 2. } 0 \\
\text { 5. } 9 \\
5.9 \\
2.8\end{array}$ & $\begin{array}{l}0.68 \\
1.6 \\
5.5 \\
4.2 \\
1.2\end{array}$ & $\begin{array}{l}111 \\
112 \\
113 \\
114 \\
115\end{array}$ & $\begin{array}{r}51 \\
149 \\
102 \\
320 \\
3450\end{array}$ & $\begin{array}{r}9.2 \\
11.9 \\
13.5 \\
4.8 \\
2.8\end{array}$ & $\begin{array}{l}5.9 \\
7.5 \\
9.9 \\
3.8 \\
0.40\end{array}$ \\
\hline $\begin{array}{l}31 \\
32 \\
33 \\
34 \\
35\end{array}$ & $\begin{array}{r}20500 \\
5700 \\
800 \\
4900 \\
2060\end{array}$ & $\begin{array}{l}1.6 \\
1.3 \\
3.4 \\
2.9 \\
1.3\end{array}$ & $\begin{array}{l}0.56 \\
0.84 \\
3.4 \\
1.1 \\
0.12\end{array}$ & $\begin{array}{l}116 \\
117 \\
118 \\
119 \\
121\end{array}$ & $\begin{array}{r}320 \\
106 \\
273 \\
10800 \\
16400\end{array}$ & $\begin{array}{r}10.1 \\
12.8 \\
8.7 \\
2.8 \\
1.4\end{array}$ & $\begin{array}{l}4.6 \\
5.3 \\
5.3 \\
1.8 \\
0.19\end{array}$ \\
\hline $\begin{array}{l}36 \\
37 \\
38 \\
39 \\
40\end{array}$ & $\begin{array}{r}11200 \\
11200 \\
38600 \\
7440 \\
970\end{array}$ & $\begin{array}{l}1.7 \\
3.7 \\
0.62 \\
2.7 \\
3.4\end{array}$ & $\begin{array}{l}0.40 \\
1.9 \\
0.53 \\
1.2 \\
1.6\end{array}$ & $\begin{array}{l}122 \\
123 \\
124 \\
125\end{array}$ & $\begin{array}{r}552 \\
6840 \\
1160 \\
5770\end{array}$ & $\begin{array}{l}3.1 \\
4.8 \\
9.0 \\
5.6\end{array}$ & $\begin{array}{l}1.4 \\
2.0 \\
1.4 \\
1.3\end{array}$ \\
\hline $\begin{array}{l}41 \\
42 \\
43 \\
44 \\
45\end{array}$ & $\begin{array}{r}1320 \\
13700 \\
60 \\
1000 \\
263\end{array}$ & $\begin{array}{l}2.0 \\
4.5 \\
4.8 \\
1.1 \\
3.1\end{array}$ & $\begin{array}{l}0.91 \\
3.0 \\
3.9 \\
1.0 \\
2.8\end{array}$ & & & & \\
\hline $\begin{array}{l}46 \\
47\end{array}$ & $\begin{array}{l}1500 \\
1770\end{array}$ & $\begin{array}{l}2.3 \\
1.0\end{array}$ & $\begin{array}{l}\text { 2. } 0 \\
0.97\end{array}$ & & & & \\
\hline
\end{tabular}

a Calculated from weight loss-time curves on data by Romanoff [1] using Faraday's law, assuming 100 percent corrosion efficiency and that the iron is divalent. For weight losses, see Romanoff [1], tables 13, 14, and 15.

b Romanoff [1], table 6

c Soil resistivity, saturated soil at $60^{\circ} \mathrm{F}$

c Soil resistivity, saturated soil at $60^{\circ} \mathrm{F}$.
d Based on first removal from soil, usually 1 to 2 years.

e Based on the best straight line on the weight loss-time curves after 5 years.

$\left.0.4 \mathrm{ft}^{2}\right)$ buried in a tidal marsh (300 $\Omega$-cm, resistivity) for a period of 32 months, the corrosion reaction was under complete cathodic control during the first week of exposure; the $I_{p} / i_{0}$ ratio was 1.3 at 8 months, and about 1.6 at 32 months when the specimen was removed (fig. 9). The ratios are believed to be approximately correct because after the specimens were removed from the trenches they were cleaned, weighed and the actual weight losses were in reasonably good agreement with the weight losses calculated from the polarization data. Thus, after 32 months (fig. 9) the current density required for cathodic protection (based on $I_{p}$, area, $0.4 \mathrm{ft}^{2}$ ) was about $8.2 \mathrm{~mA} / \mathrm{ft}^{2}$. Similar polarization data on steel specimens of the same size were obtained by Ardahl 


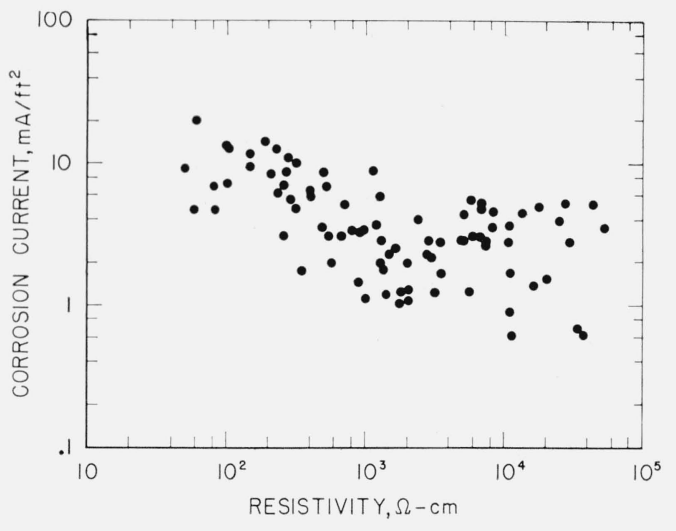

Figure 6. Corrosion current densities calculated from the weight losses of the specimens (fig. 1) after removal from the underground sites upon 2 years of exposure.

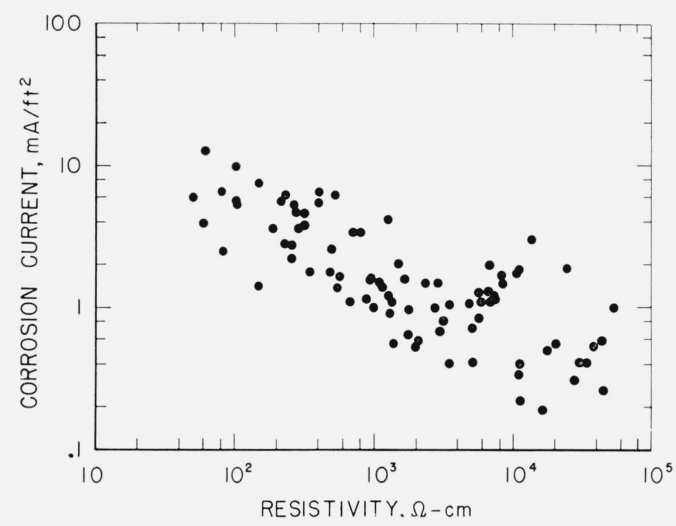

Figure 7. Calculated corrosion current densities based on the rates of weight loss between 5 and 12, and between 5 and 17 years of exposure for the majority of soils.

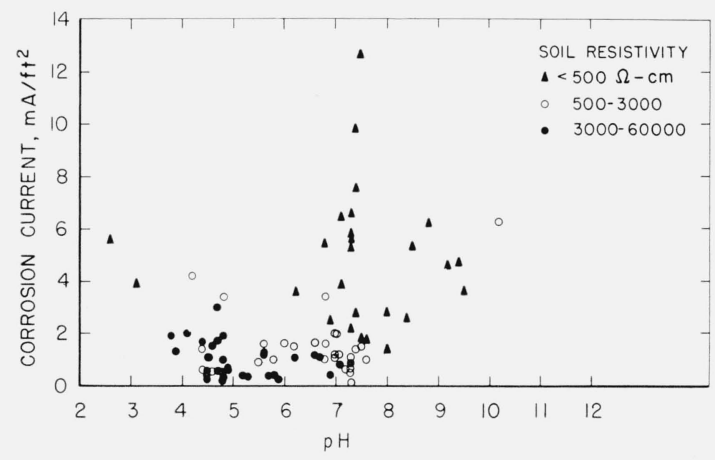

FIGURE 8. Same as figure $\%$, except as related to $\mathrm{pH}$ for 3 ranges of soil resistivity.

[17]. The writer analyzed these data and observed that after 2 years of underground exposure, in 2 soils with resistivities between 550 and $1000 \Omega$-cm, the $I_{p} / i_{0}$ ratio was between 1.1 and 1.8 .

In higher resistivity soils (greater than $10,000 \Omega-\mathrm{cm}$ ), the $I_{p} / i_{0}$ ratio is probably about 2 or more, depending

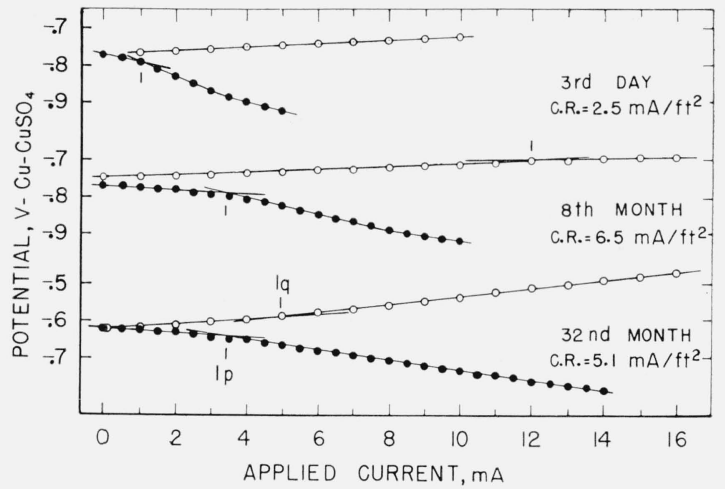

Figure 9. Polarization curves on a plain steel specimen buried underground for 32 months in a tidal marsh.

$$
0 \text { anodic } \bullet \text { cathodic }
$$

on soil properties and on duration of exposure. In a laboratory study, [18] a steel tube (area, 24 in..$^{2}$ ) was exposed to a $20,000 \Omega-\mathrm{cm}$ sandy loam soil for 60 days. The current density necessary for cathodic protection was found to be about 3 times the value of current density associated with the weight losses of similar tubes which were permitted to corrode freely, that is, the $I_{p} / i_{0}$ ratio was about 3 .

On the basis of the foregoing $I_{p} / i_{0}$ ratios, the corrosion current densities given in table 2 and in figures 6 and 7 might be increased accordingly and thus converted to values necessary for cathodic protection. This does not mean that current densities are substituted for polarization requirements as criteria [11] for cathodic protection. The protective current densities are presented to aid in estimating total current requirements in the design of underground cathodic protection systems. It would seem reasonable to multiply the corrosion current densities by 1.5 for soils having resistivities between 0 and 5000 $\Omega-\mathrm{cm}$. A factor of 2.0 might be used for soils with resistivities between 5000 and $10,000 \Omega-\mathrm{cm}$. Above $10,000 \Omega$-cm, the $I_{p} / i_{0}$ ratio could be taken as being 3.0 and still result in relatively small protective current densities for most high resistivity soils.

A comparison of the corrosion current densities in the two columns (table 2) and of Figures 6 and 7 shows that it would be economically advisable, at least for uncoated underground structures, to allow about 2 years before designing the electrical requirements for cathodic protection. The current densities necessary for cathodic protection are considerably reduced after a few years of exposure, especially in the soils of high resistivity.

\section{Conclusions}

The maximum pit depths on commonly used wrought ferrous materials buried for periods up to 5 years in back-filled trenches are on the average deeper in soils with resistivities below $500 \Omega$-cm than in soils having higher resistivities while in the soils above $500 \mathrm{ohm}-\mathrm{cm}$, there appears to be no regular pattern between maximum pit depth and soil resistivity. However, for periods of exposure in excess 
TABLE 3. Average values of maximum penetration rate and corrosion rate (current) on specimens for 3 ranges of soil resistivity after 5 years of exposure

\begin{tabular}{|c|c|c|c|c|c|c|c|}
\hline \multirow{2}{*}{ Soil resistivity } & \multirow{2}{*}{$\begin{array}{l}\text { Number } \\
\text { of soil } \\
\text { sites }\end{array}$} & \multicolumn{3}{|c|}{$\underset{\text { rate }^{\mathrm{a}}}{\text { Maximum petration }}$} & \multicolumn{3}{|c|}{$\begin{array}{l}\text { Corrosion } \\
\text { current b }\end{array}$} \\
\hline & & Min & Avg & $\operatorname{Max}$ & Min & Avg & Max \\
\hline $\begin{array}{l}\quad \Omega-c m \\
50 \text { to } 500 \\
500 \text { to } 3000 \\
3000 \text { to } 54,000\end{array}$ & $\begin{array}{l}26 \\
28 \\
32\end{array}$ & $\begin{array}{r}0.84 \\
.60 \\
.28\end{array}$ & $\begin{array}{r}\text { mils/yr } \\
11.4 \\
4.2 \\
2.2\end{array}$ & $\begin{array}{r}35.0 \\
12.6 \\
6.7\end{array}$ & $\begin{array}{c}1.4 \\
.12 \\
.19\end{array}$ & $\begin{array}{l}m A / f t^{2} \\
\quad 4.8 \\
1.6 \\
0.99\end{array}$ & $\begin{array}{r}12.7 \\
6.2 \\
3.0\end{array}$ \\
\hline
\end{tabular}

a Calculated from the specimen pitting rates after 5 years (table 1 ).

b Calculated from the corrosion rates (currents) after 5 years (table 2).

of 5 years, the rate of maximum penetration lessens as the soil resistivity increases beyond $500 \Omega-\mathrm{cm}$. This is shown in table 3 where data from 86 soil sites are averaged for 3 ranges of soil resistivity. Based on an empirical equation, increasing the area exposed to that equivalent to a $20 \mathrm{ft}$ length of $8 \mathrm{in}$. diam pipe (45.16 $\left.\mathrm{ft}^{2}\right)$ approximately doubles the maximum penetration rates shown in the table which apply to the actual specimens $\left(0.4 \mathrm{ft}^{2}\right)$.

In soils with resistivities up to $500 \Omega$-cm, perforation of thick-wall (0.322 in.) bare wrought ferrous pipe is predicted in the majority of soils after 15 years of exposure. After 30 years of exposure, the same would be true probably in the majority of soils having resistivities to $1000 \Omega$-cm; in some of these soils many perforations would be likely to occur.

After the corrosion rates of the ferrous specimens became fairly well stabilized as shown by weight Ioss-time curves, the weight losses were converted to current densities. Corrosion current densities, averaged for three ranges of soil resistivity, are given in table 3 . The current densities required for cathodic protection are greater than the current densities associated with the corrosion. By anticipating the type of corrosion control peculiar to the corrosive environment, corrosion current densities can be adjusted to current densities necessary for cathodic protection. A factor of 1.5 is suggested for soils with resistivities up to $5000 \Omega-\mathrm{cm}$, a factor of 2.0 for soils from 5000 to $10,000 \Omega-\mathrm{cm}$, and a factor of 3.0 for soils with resistivities above $10,000 \Omega$-cm. It is considered to be economically advisable to wait for about 2 years of exposure before measuring the current densities required for the cathodic protection of bare underground structures.

\section{References}

[1] Melvin Romanoff, Underground corrosion, NBS circ. 579, U.S. Government Printing Office, Washington, D.C. (1957).

[2] Kirk H. Logan, Engineering significance of National Bureau of Standards soil-corrosion data, J. Res. NBS 22, 109 (1939) RP1171.

[3] Gordon N. Scott, The distribution of soil conductivities and some consequences, Corrosion 14, 396t (August 1958).

[4] Edward Schaschl and Glenn A. Marsh, Some New Views on Soil Corrosion, Materials Protection 2 , 8 (November 1963).

[5] Melvin Romanoff, Corrosion of steel pilings in soils, J. Res. NBS 66C (Eng. and Instr.) No. 3,223 (July-Sept. 1962).

[6] G. N. Scott, Adjustment of soil-corrosion pit depth measurements for size of sample, Proc. American Petroleum Institute 14, No. 4, 204 (1933).

[7] K. H. Logan, S. P. Ewing, and I. A. Denison, Soil corrosion testing, Symposium on Corrosion Testing Procedures, ASTM (1937).

[8] W. J. Schwerdtfeger, Laboratory measurement of the corrosion of ferrous metals in soils, J. Res. NBS 50, 329 (June 1953) RP2422.

[9] Gordon N. Scott, Distribution of soil conductivity and its relation to underground corrosion, Journal A WWA 52, 378 (March 1960).

[10] Gordon N. Scott, A theory for the probability distribution of soil conductivity, Corrosion 18, 251t (July 1962).

[11] W. J. Schwerdtfeger and O. N. McDorman, Potential and current requirements for the cathodic protection of steel in soils, J. Res. NBS 47, 104 (August 1951) RP2233; Corrosion 8, 391 (1952)

[12] W. J. Schwerdtfeger and O. N. MeDorman, Measurement of the corrosion rate of a metal from its polarizing characteristics, J. Electrochem. Soc. 99, 407 (1952).

[13] I. A. Denison, Electrolytic behavior of ferrous and nonferrous metals in soil-corrosion circuits, Trans. Electrochem. Soc. 81, 435 (1942).

[14] Robert Pope, Cell currents and potentials, Corrosion 11, $189 \mathrm{t}$ (April 1955).

[15] E. Schaschl and G. A. Marsh, The effect of dissolved oxygen on corrosion of steel and on current required for cathodic protection, Corrosion 13, 243t (April 1957).

[16] W. J. Schwerdtfeger, A Study by polarization techniques of the corrosion rates of aluminum and steel underground for sixteen months, J. Res. NBS 65C (Eng. and Instr.) No. 4, 271 (Oct.-Dec. 1961).

[17] E. H. Ardahl, Corps of Engineers, U.S. Army, Lower Mississippi Valley Division, Vicksburg, Miss. (private correspondence).

[18] W. J. Schwerdtfeger, Current and potential relations for the cathodic protection of steel in a high resistivity environment, J. Res. NBS 63C, 37 (July-Sept. 1959); Corrosion 16, 209t (May 1960).

(Paper 69C1-188) 